\title{
Determination of Carbapenemase Producing of Klebsiella pneumoniae Isolated in Blood Cultures By Matrix Assisted Laser Desorption/Ionization-flight Time Mass Spectrometry
}

\section{Kan Kültürlerinde Üreyen Klebsiella pneumoniae Sușlarında, Karbapenemaz Üretiminin Matriks Destekli Lazer Desorpsiyon/İyonizasyonu-Uçuș Zamanı Kütle Spektrometresi ile Belirlenmesi}

\section{Metin DOG̃AN'(iD), Abdullah Yücel BABA²(iD)}

\footnotetext{
${ }^{1}$ Department of Medical Microbiology, Faculty of Meram Medicine, University of Necmettin Erbakan, Konya, Turkey

${ }^{2}$ Health Services Vocational School, University of Ankara Medipol, Ankara, Turkey
}

Cite this article as: Doğan M, Baba AY. Determination of carbapenemase producing of Klebsiella pneumoniae isolated in blood cultures by matrix assisted laser desorption/ionization-flight time mass spectrometry. FLORA 2020;25(2):236-44.

\begin{abstract}
Introduction: Klebsiella pneumoniae can cause Healthcare Related Infections (HRIs), especially by carbapenemase producing microorganisms. Rapid methods are needed to determine carbapenem resistance. MALDI-TOF MS is a faster diagnostic method than conventional methods. It is expected that routine use and standardization of this diagnostic test in laboratories will contribute to the rapid determination of carbapenemase resistance. In this study, it was aimed to determine carbapenemase enzyme production by MALDI-TOF MS technique in K. pneumoniae strains.
\end{abstract}

Materials and Methods: Carbapenem susceptible $(n=40)$ and non-susceptible $(n=96) \mathrm{K}$. pneumoniae strains isolated in the Medical Microbiology Laboratory between January 2016 to December 2017 were included into the study. Detecting of production of carbapenemase enzyme was investigated by MALDI-TOF MS technique by comparing with the polymerase chain reaction (PCR).

Results: PCR analysis showed that 93 of the carbapenem resistant isolates had OXA-48 gene and three of them had NDM gene. In the MALDI-TOF MS analyzes of the 96 isolates with genotypic resistance, 88 were resistant and three were susceptible. Five isolates of carbapenem resistant with PCR could not be identified as resistant or sensitive by this method. Forty isolates susceptible to carbapenem were determined to be susceptible by MALDI-TOF MS. Sensitivity, specificity, positive predictive, negative predictive values were $96.7 \%$, $100 \%, 100 \%, 93 \%$ respectively.

Conclusion: It appears that MALDI-TOF MS determines carbapenemase production with high specificity and sensitivity. We think it will be beneficial to complete standardization studies and use them in routine practice.

Key Words: Klebsiella pneumoniae; Carbapenemase; OXA-48; NDM; MALDI-TOF MS.

${ }^{\oplus}$ Copyright 2020 by Flora. Available on-line at www.floradergisi.org. 


\title{
ÖZ
}

\section{Kan Kültürlerinde Üreyen Klebsiella pneumoniae Sușlarında, Karbapenemaz Üretiminin Matriks Destekli Lazer Desorpsiyon/Iyonizasyonu-Uçuș Zamanı Kütle Spektrometresi ile Belirlenmesi}

\author{
Metin DOG̃AN', Abdullah Yücel BABA ${ }^{2}$ \\ ${ }^{1}$ Necmettin Erbakan Üniversitesi Meram Tıp Fakültesi, Tıbbi Mikrobiyoloji Anabilim Dalı, Konya, Türkiye \\ 2 Ankara Medipol Üniversitesi Sag̃lık Hizmetleri Meslek Yüksekokulu, Ankara, Türkiye
}

\begin{abstract}
Giriş: Klebsiella pneumoniae suşları, özellikle de karbapenemaz üreten türleri, sağlık hizmeti ile ilişkili infeksiyonlara neden olabilmektedir. Karbapenem direncinin belirlenebilmesi için hızlı yöntemlere ihtiyaç duyulmaktadır. MALDI-TOF MS, geleneksel yöntemlerden daha hızlı bir tanı yöntemidir. Bu tanı testinin laboratuvarlarda rutin kullanılmasının ve standart hale getirilmesinin karbapenamaz direncinin hızlı belirlenmesine katkı sunacağı beklenmektedir. Bu çalışmada K. pneumoniae suşlarında karbapenemaz enzimi üretiminin MALDITOF MS tekniği ile belirlenmesi amaçlanmıştır.
\end{abstract}

Materyal ve Metod: Ocak 2016-Aralık 2017 tarihleri arasında Tıbbi Mikrobiyoloji Laboratuvarında izole edilen, karbapeneme duyarlı $(n=40)$ ve duyarlı olmayan $(n=96) \mathrm{K}$. pneumoniae suşları çalışmaya dahil edildi. MALDI-TOF MS tekniğinin karbapenemaz enzim üretimini tespit edebilme durumu polimeraz zincir reaksiyonu (PCR) ile karşılaştırılarak araştırıldı.

Bulgular: Yapılan PCR analizinde, karbapeneme dirençli izolatların 93'ünün OXA-48 genine ve üçünün NDM genine sahip olduğu görülmüştür. Genotipik olarak dirençli olan 96 izolatın MALDI-TOF MS'deki analizlerinde 88'i dirençli, üçü duyarlı olarak belirlenmiştir. Bu yöntemle beş karbapenem izolatının dirençli veya duyarlı olduğu tespit edilememiştir. Karbapeneme duyarlı 40 izolatın MALDI-TOF MS tarafından duyarlı olduğu tespit edilmiştir. Duyarılık, özgüllük, pozitif prediktif ve negatif prediktif değerleri sırasıyla \%96.7, \%100, $\% 100$ ve \%93'tür.

Sonuç: MALDI-TOF MS'nin karbapenemaz üretimini belirlemede yüksek bir özgüllük ve duyarllığa sahip olduğu görülmektedir. Standardizasyon çalışmaları tamamlanarak rutinde bu tekniği kullanmanın faydalı olacağını düşünüyoruz.

Anahtar Kelimeler: Klebsiella pneumoniae; Karbapenemaz; OXA-48; NDM; MALDI-TOF MS.

\section{INTRODUCTION}

Klebsiella pneumoniae, included in the Enterobacteriaceae family, is the microflora bacteria of the gastrointestinal tract and can cause Healthcare Related Infections (HRIs). These species, which are among the opportunistic pathogens, can cause various infections, especially in immunocompromised patients ${ }^{[1]}$. K. pneumoniae, the most important species in this genus, often causes hospital-acquired urinary tract infections, pneumonia, sepsis and soft tissue infections. Healthcare workers' hands, mechanical ventilators apparatus, catheters and surgical wounds are important predisposing factors for Klebsiella infections and fecal-oral transmission is plausible $e^{[2,3]}$.

Due to beta-lactamase enzymes synthesized by pathogens, difficulties are experienced in the treatment of infections caused by Enterobacteriaceae, including $K$. pneumoniae, which are generally treated with beta-lactam antibiotics. Beta-lactama- ses and carbapenems are bacterial enzymes wellknown for causing antibiotic resistance. Especially in the Enterobacteriaceae family, carbapenemase producing isolates have increased significantly in recent years ${ }^{[4]}$.

Carbapenems are one of the most broad-spectrum beta-lactam antibiotics, and treatment options are restricted since microorganisms have developed resistance to carbapenems. The beta-lactamases hydrolyzing carbapenems are classified in class $\mathrm{A}, \mathrm{B}$ and $\mathrm{D}$ in the Ambler classification. $K$. pneumoniae carbapenemase (KPC), which is one of the first identified carbapenemases, is in the class $A$ and is transferred via plasmid ${ }^{[5]}$. In class $\mathrm{B}$, whereas Verona integron-encoded metallo-beta-lactamase (VIM) and imipenem-hydrolysing beta-lactamase (IMP) are found, and oxacillin-hydrolyzing carbapenemase (OXA) enzymes are in class D. OXA-48 is the best known enzyme in the OXA group and is widely available in Turkey 
and worldwide ${ }^{[6,7]}$. New carbapenemases have been reported in Enterobacteriaceae and non-fermentative bacilli ${ }^{[7]}$.

OXA-48 carbapenemase-producing strains are endemic in Turkey in terms of the spread of carbapenemase types among European countries. Furthermore, New Delhi metallo-beta-lactamase (NDM-1) type carbapenemases have rapid spread, and VIM type carbapenemases often cause outbreaks in hospitals. Several researches have reported that it is the focal point in India, United States, Israel, Greece and Italy for NDM, and Turkey and North African countries to OXA-48, and India for KPC. OXA-48 was first reported in our country in 2003 and continues to be reported intensively ${ }^{[7,8]}$

Carbapenem-resistant microorganism infections are associated with high mortality and morbidity due to limited availability of treatment options. However, the increase of carbapenem resistance provides depletion of antibiotic alternatives necessary for the treatment of these infections and an environment for the rapid dissemination of resistance. In Turkey, the rate of increase in infections caused by carbapenemase-producing Klebsiella species is higher than the other regions of the world ${ }^{[7,9,10]}$.

Identification of carbapenemase-producing clinical isolates is necessary for the treatment of infections caused by these isolates, to prevent spread of resistance genes, and for prevention of hospital infections ${ }^{[11]}$. For the identification of carbapenemase-producing bacteria, conventional methods such as Modified Hodge gradient test (MHT), double disk synergy test, and using the inhibitors and molecular methods have been utilized. In addition to these tests, Matrix assisted laser desorption/ionization-flight time mass spectrometry (MALDI-TOF MS) is one of the new methods used in this field ${ }^{[12-16]}$.

MALDI-TOF MS is a method that analyzes different flight behavior of the released molecules by providing ionization of the sample with a laser that can determine the production. The peak diagram of meropenem can be shown in carbapenem-sensitive isolates. But these peak diagrams decrease in carbapenemase producing strains $^{[12-16]}$.
Difficulties have been experienced in identifications of OXA-48. The presence of these enzymes should be confirmed by other methods since no inhibitor is present for OXA-48-like enzyme-producing bacteria ${ }^{[17]}$. Therefore, it is needed to develop rapid identification systems such as MALDI-TOF MS to determine of OXA-48 like carbapenamase enzymes.

In this study, it was aimed to determine carbapenemase enzymes produced by $K$. pneumoniae strains by using MALDI-TOF MS technique used in the identification of microorganisms in microbiology laboratories.

\section{MATERIALS and METHODS}

$K$. pneumoniae strains were isolated from the blood samples in Medical Microbiology Laboratory of Necmettin Erbakan University Medical Faculty Hospital between January 2016 and December 2017. Ninety-six of the isolates resistant to imipenem and meropenem and 40 isolates sensitive to imipenem and meropenem according to EUCAST criteria were included into this study. All bacteria were stored at $-20^{\circ} \mathrm{C}$ in $15 \%$ glycerin-containing stock. Ethical review and approval were sought from Meram Faculty of Medicine Research and Ethics Committee (Approval No: 2017/1092)

Identification of the bacteria was performed with VITEK $^{\circledR}$ MS MALDI-TOF (BioMerieux, France), an automated identification system and the system's software was used (SARAMIS v4.12 program). $K$. pneumoniae strains that were defined with above $98 \%$ safety by the evaluation (giving specific peaks in Figure 1) of the system in the database were included into the study. Bacteria identified with safety lower than this were not included into the study. Confirmations of 96 $K$. pneumoniae isolates that were imipenem and meropenem resistant were performed by gradient test methods.

The synergy test with meropenem discs combined with aminophenyl boronic acid, phenyl boronic acid, dipicolinic acid and cloxacillin was performed. If synergy was not observed and temocillin disc $(30 \mu \mathrm{g})$ formed a lower zone at 10 $\mathrm{mm}$, phenotyping determinant for OXA-48 was accepted. 


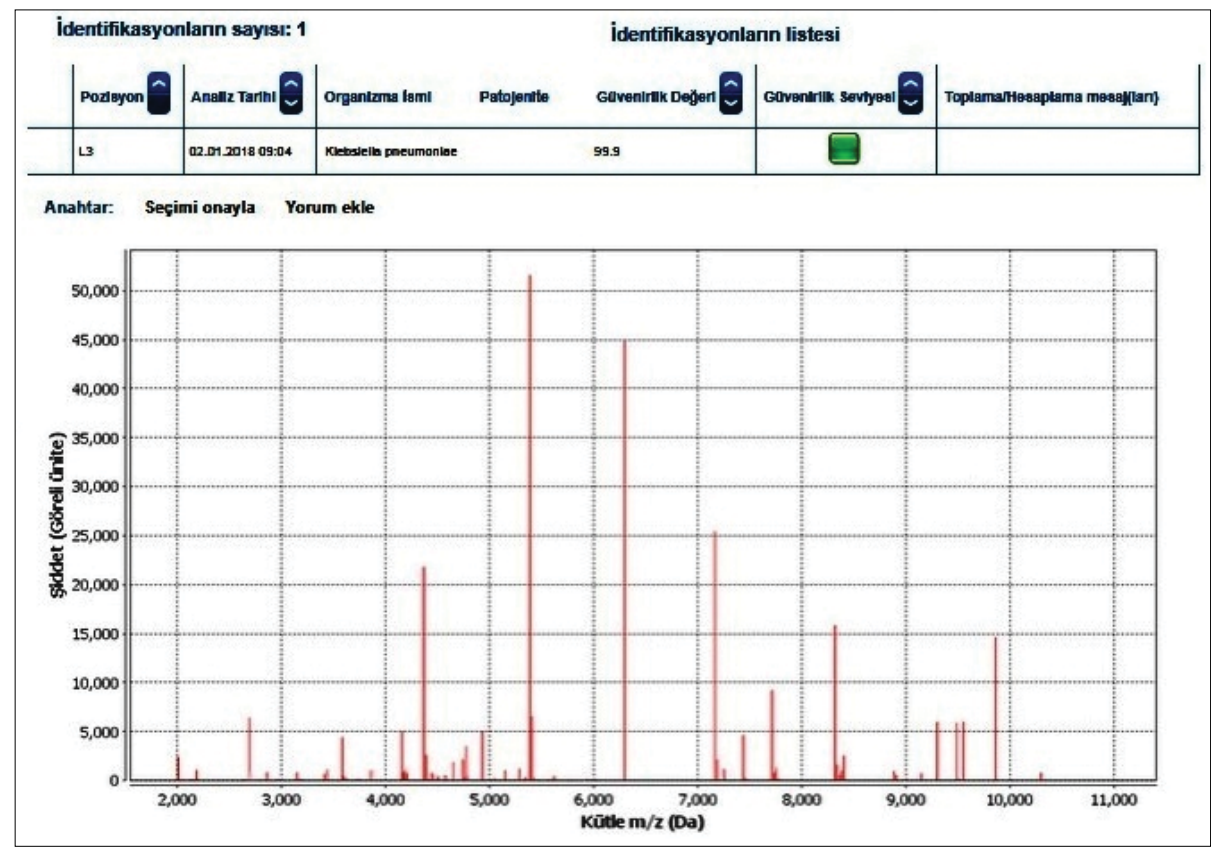

Figure 1. Representative MALDI-TOF MS spectra of bacteria identified as Klebsiella pneumoniae.

Polymerase chain reaction (PCR) analysis of these isolates was performed to determine the resistance genes OXA-48 and NDM. In order to identify bacterial resistance genes and see growth curves in real-time $\mathrm{PCR}$, the primer was determined and the following primer sequences were used. For NDM-1; forward primer: 5'-TTGGCCTTGCTGTCCTTG-3', reverse primer: 5'-ACACCAGTGACAATATCACCG-3', and for OXA-48; forward primer: 5'-TGTTTTTGGTGGCATCGAT-3', reverse primer: 5'-GTAAMRATGCTTGGTTCGC-3' primers were used. DNA amplification was performed using a real-time PCR system (Roche Light Cycler 480 Instrument II, Switzerland).

When samples in stock media were at room temperature, they were then cultivated on blood agar and incubated overnight at $35^{\circ} \mathrm{C}$. Suspensions were prepared to study of $\mathrm{VITEK}^{\circledR}$ MALDI-TOF MS. Three $\mathrm{mL}$ of $150 \mathrm{mM} \mathrm{NaCl}$, and $20 \mathrm{mM}$ Tris- $\mathrm{HCl}$ solution was transferred to each test tube. Bacterial suspensions were prepared to four McFarland densities. One $\mathrm{ml}$ each of these prepared three $\mathrm{ml}$ suspension was transferred to microcentrifuge tubes. The samples were then centrifuged at $4000 \mathrm{rpm}$ for three minutes. After centrifugation, the supernatants were discarded,
$50 \mu \mathrm{L}$ solution containing $150 \mathrm{mM} \mathrm{NaCl}, 20$ $\mathrm{mM}$ TRIS $\mathrm{HCl}$ and $20 \mathrm{mM}$ meropenem were added to the tubes. This solution was incubated at $35^{\circ} \mathrm{C}$ for 3 hours. Subsequently, the composition was centrifuged at $14000 \mathrm{rpm}$ three min. In order to study MALDI-TOF, one $\mu \mathrm{L}$ of the supernatant was taken and the preparation was prepared.

The sample prepared from the supernatant was analyzed by VITEK $^{\circledR}$ MS MALDI TOF (SARAMIS v4.12 program) (BioMerieux, France). The peaks of meropenem and bacteria were assessed in the MALDI-TOF MS. The results were compared with genotypic evaluation.

\section{RESULTS}

OXA-48 gene in 93 isolates and NDM gene in three isolates were revealed in genotypic analysis of the 96 carbapenem resistant isolates.

In the MALDI-TOF MS analysis, the peaks in the MALDI-TOF MS formed in meropenem only are shown in Figure 2. The peaks formed by carbapenem-sensitive isolate are shown in Figure 3. The peak diagram of the carbapenem-resistant isolate is shown in Figure 4. As shown in Figure 4 , if the meropenem peak was observed to fall (a lack of the $\mathrm{m} / \mathrm{z} 380-383$ peaks), the tested 


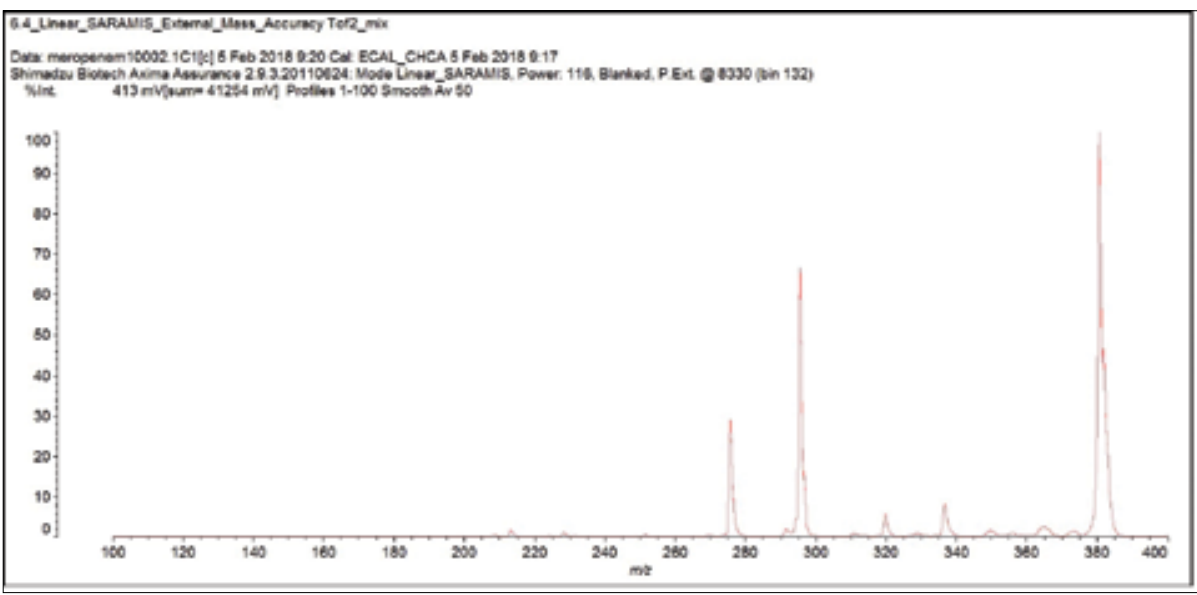

Figure 2. Representative MALDI-TOF MS spectra of meropenem without bacteria.

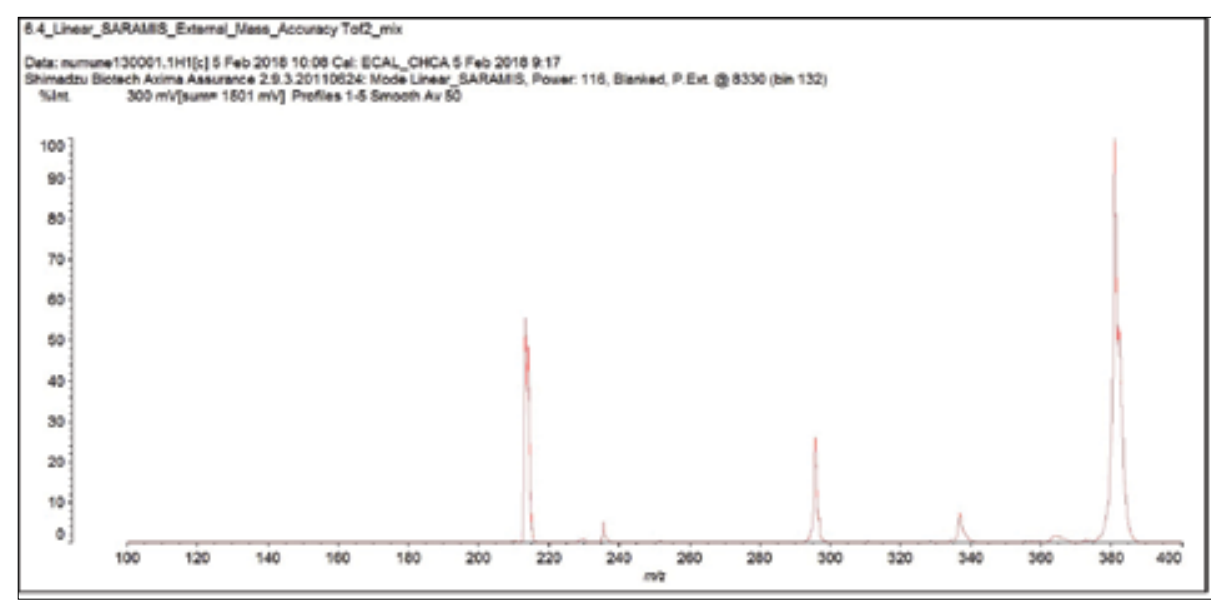

Figure 3. Representative MALDI-TOF MS spectra of meropenem and of carbapenem susceptible isolate.

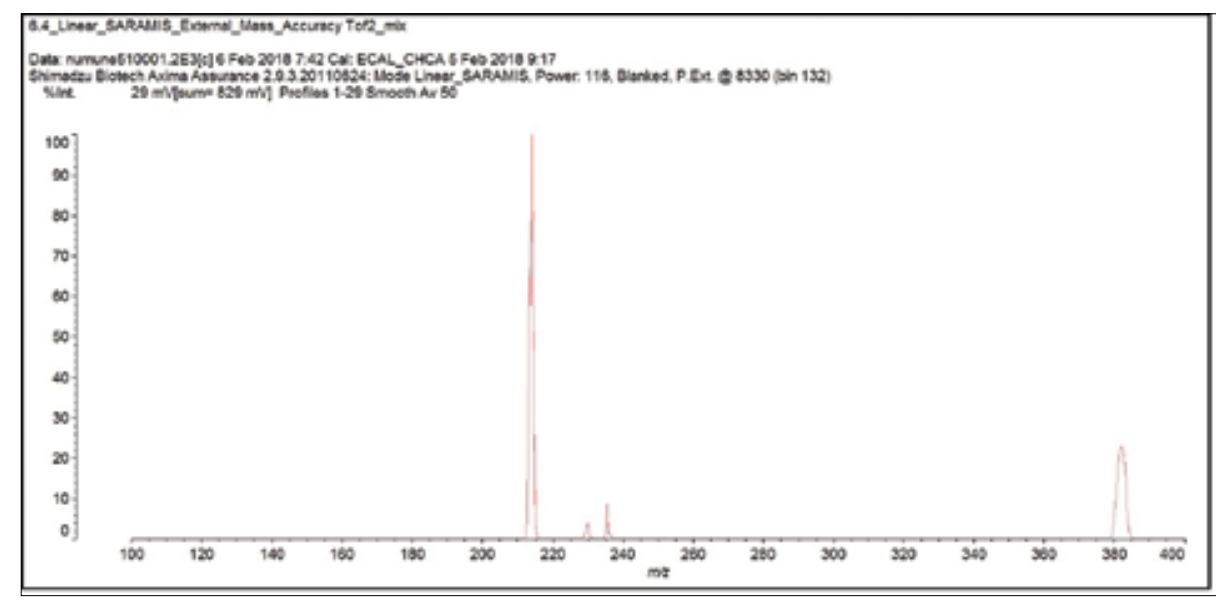

Figure 4. Representative MALDI-TOF MS spectra of meropenem and of carbapenem resistant isolate. 
strain was considered to have carbapenemase production. If both the bacterium and meropenem peaks were as seen in Figure 3 (a decrease in bacteria peak over time), it was accepted to produce no carbapenemase.

In the MALDI-TOF MS analysis of 96 isolates which have genotypic resistance genes, 88 of them were found to be resistant to carbapenem (producing carbapenemase) and three of them were found to be no resistant although they are resistant genetically. MALDI-TOF MS analysis could not observe whether five isolates were resistant or sensitive. Sensitivity of five isolates was not detected by MALDI-TOF MS analysis. No false positive results were seen.

This method had a sensitivity of $96.7 \%$, specificity of $100 \%$, positive predictive value (PPV) of $100 \%$ and negative predictive value (NPV) of 93\% for the detection of producing carbapenemase compared with genetically analyzing (PCR). Failure to make any comments for five isolates reduces the efficiency of the test.

\section{DISCUSSION}

It is frequently observed that the members of carbapenemase-producing Enterobacteriaceae have low levels of carbapenem resistance, which can lead to misleading results related to MIC values. The detection of low-level carbapenemase-expressing infectious agents is not always possible according to the limit values determined by international guidelines. Especially, OXA-48-expressing strains are generally low levels of carbapenemase producers and there is no phenotypic method with a high diagnostic value that can be used for the detection of OXA-48 in carbapenem-resistant strains ${ }^{[18]}$. Therefore, it is rationally predictable that a single carbapenem screening criterion cannot be used to specifically identify carbapenemase-expressing strains. Thus, confirmatory tests is essential for the detection of especially carbapenemase-producing Enterobacteriaceae ${ }^{[18,19]}$. This situation causes problems such as increase in workload, economic loss and most importantly, longer detection period.

Currently, there are studies reporting that the sensitivity of conventional methods in the detection of beta-lactamases and carbapenemases is generally high. For example, Miriagou et al., using MHT method to detect carbapenemase in Enterobacteriaceae species, have observed that the test had a sensitivity of $95-100 \%[20]$. Ribeiro et al. aimed at assessing the performance of a quantitative interpretation of MHT in a study of concerns about difficult interpretation and widespread false positive results in the presence of beta-lactamases $^{[21]}$. At the end of the study, the sensitivity of the test was obtained as $99.4 \%$. Similarly, Legese et al. have reported that they had $90.9 \%$ sensitivity of the double-disc synergy test used in the detection of beta-lactamase and carbapenemase production in their study in the members of Enterobacteriaceae causing infection in pediatric patients ${ }^{[22]}$. Pasteran et al. have reported that they obtained $86-100 \%$ sensitivity in the detection of carbapenemase-producing bacteria in their study using the combined disc synergy test, which is a phenotypic method ${ }^{[23]}$.

The most important disadvantage of conventional methods with high sensitivity percentages in the detection of beta-lactamase/carbapenamase is the longer incubation time. At the same time, there is a need for long time for analyzing by PCR in practice. However, the cost of consumables is very low, but the cost of installation and maintenance of MALDI-TOF MS is high. On the other hand, with automated systems such as MALDI-TOF MS, results with high sensitivity percentages can be obtained in a short time. In addition to allowing identification directly from the patient sample, antibiotic susceptibility detection and enzyme level distinctions such as carbapenemase may be detected in the future ${ }^{[24]}$.

MALDI-TOF MS is an automated method increasingly used in the identification of various infectious agents at routine works and in research laboratories. There are many advantages of this method, including high sensitivity and specificity, short analysis time, and etc. This method that analyzes different flight behavior of the released molecules by providing ionization of the sample with the laser can determine the production of carbapenemase in a short time by the detection of the hydrolytic products of carbapenems in the case of carbapenemase expression of the infectious agent, too ${ }^{[25,26]}$. 
Optimizing the MALDI-TOF MS method by diversifying the solutions used in the extraction, the antibiotic to be used in the analysis, and incubation times will be important milestones in laboratory diagnosis of carbapenemase detection. Thus, the method will be used more widely for carbapenemase detection ${ }^{[13,27]}$.

In a study using the MALDI-TOF MS method, MALDI-TOF MS method has been confirmed in Enterobacteriaceae members and Pseudomonas aeruginosa with carbapenemase-mediated carbapenem resistance with other methods ${ }^{[28]}$. Of the 124 strains included in the study, 30 were observed carbapenemase-producing by conventional methods. When investigated producing carbapenemase with MALDI-TOF MS, the sensitivity and specificity of the method were determined as $96.67 \%$ and $97.87 \%$, respectively. The results have showed that this method can be routinely used to detect carbapenemases in Enterobacteriaceae members and Pseudomonas species ${ }^{[28]}$

In another study on the rapid detection of carbapenemase-producing Enterobacteriaceae members using MALDI-TOF MS, a total of 105 strains of various carbapenemase-producing and non-producing strains have been identified and tested using this method. Imipenem hydrolysis analyses followed by mass spectrometry to determine the breakdown of the antibiotic were used. As a result, when the data were checked by PCR, the tests showed $87 \%$ sensitivity and $100 \%$ specificity ${ }^{[29]}$.

Similarly, direct carbapenemase activities from blood culture samples have been determined using MALDI-TOF MS. A total of 100 blood culture samples have been analyzed for carbapenemase by MALDI-TOF MS and compared with molecular methods. Of the 110 isolated bacterial isolates, when 29 were found to produce carbapenemase with molecular methods, 21 were found with MALDI-TOF MS (72.4\%) ${ }^{[30]}$.

In another study, in performed MALDI-TOF MS analysis using ertapenem in $P$. aeruginosa strains, it could be able to detect strains having KPC only after 15 minutes of incubation, but only $8(57 \%)$ of 14 isolates having VIM were identified correctly ${ }^{[31]}$.
As seen in the above studies, studies on this subject are in progress.

In the present study, OXA-48 was shown in 93 out of 96 isolates, and NDM-1 was found in three of them. This study showed that resistance development in the carbapenamase-producing $K$. pneumoniae strains was associated with OXA-48 in our region generally. Previously, in the Konya region, OXA-48 had been observed in four $K$. pneumoniae strains and two of them had NDM-1 at the same time. No other study has been found in the literature related to these bacterial species in our region ${ }^{[32]}$. Considering the difficulties in demonstrating carbapenem resistance in OXA-48 strains, it is important to demonstrate a new method in this study ${ }^{[17]}$.

In this study, sensitivity was obtained as 96.7\%, and specificity and PPV were 100\% and NPV was 93\%. Sensitivity and other data obtained in our study are similar to other studies. Failure to make any comments for five isolates reduced the efficiency of the test. This method is more advantageous than other methods because of high sensitivity and specificity, and short analysis time. It seems that complete standardization can not be achieved due to the recent use of the method in this field and the lack of sufficient data in the literature yet.

MALDI-TOF MS, which has been used in identification and antibiotic susceptibility studies, is a relatively new application in this area, and it has been observed that the sensitivity of determination of carbapenem resistance is high and it is observed faster than phenotypic methods. On the other hand, new studies are needed to determine standardization, specificity, and sensitivity of antimicrobial susceptibility detection and determination of carbapenemase.

To conclude, it appears that MALDI-TOF MS determines carbapenemase production with high specificity and sensitivity. We think it will be beneficial to complete standardization studies and use them in routine practice.

\section{ACKNOWLEDGEMENT}

This study supported by Necmettin Erbakan University Scientific Research Projects with project number of 181318007. 


\section{ETHICS COMMITTEE APPROVAL}

Ethical review and approval were sought from Meram Faculty of Medicine Research and Ethics Committee (Approval No: 2017/1092).

\section{CONFLICT of INTEREST}

The authors declare that they have no conflict of interest.

\section{AUTHORSHIP CONTRIBUTIONS}

Concept/Design: MD

Analysis/Interpretation: AYB

Data Acquisition: AYB

Writting: MD

Final Approval: MD

\section{REFERENCES}

1. Bagley ST. Habitat association of Klebsiella species. Infection control: IC. 1985;6(2):52-8.

2. Gupta A. Hospital-acquired infections in the neonatal intensive care unit-K. pneumoniae. Semin Perinatol 2002;26(5):340-5.

3. Seibert $G$, Hörner $R$, Meneghetti $B H$, Righi RA, Dal Forno $N L$, Salla A. Nosocomial infections by Klebsiella pneumoniae carbapenemase producing enterobacteria in a teaching hospital. Einstein 2014;12(3):282-6.

4. Adler A, Katz DE, Marchaim D. The continuing plague of extended-spectrum $\beta$-lactamase-producing Enterobacteriaceae infections. Infect Dis Clin North Am 2016;30(2):347-75.

5. Jarvis WR, Munn VP, Highsmith AK, Culver DH, Hughes JM. The epidemiology of nosocomial infections caused by Klebsiella pneumoniae. Infect Control 1985;6(2):68-74.

6. Çiftçi H, Karakeçe E, Aşık G, Demiray T, ER H. Karbapenem dirençli Klebsiella pneumoniae suşlarında OXA-48 ve KPC varlığının araştırılması. Ankem Derg 2013;27(2):49-54.

7. Nordmann P, Naas T, Poirel L. Global spread of carbapenemase-producing Enterobacteriaceae. Emerg Infect Dis 2011;17:1791-98.

8. Nordmann P. The difficult-to-control spread of carbapenemase producers among Enterobacteriaceae worldwide. Clin Microbiol Infect 2014;20(9):821-30.

9. Kılıç A, Baysallar M. The first Klebsiella pneumoniae isolate co-producing OXA-48 and NDM-1 in Turkey. Ann Lab Med 2015;35:382-3.

10. Karabay $O$, Altindis $M$, Koroglu M, Karatuna O, Aydemir ÖA, Erdem AF. The carbapenem-resistant Enterobacteriaceae threat is growing: NDM-1 epidemic at a training hospital in Turkey. Ann Clin Microbiol Antimicrob 2016;15:6.

11. Endimiani $A$, Choudhary $Y$, Bonomo $R$. In vitro activity of $N X L 104$ in combination with $\beta$-lactams against Klebsiella pneumoniae isolates producing KPC carbapenemases. Antimicrob Agents Chemother 2009;53:83599-601.
12. Livermore DM, Brown DFJ. Detection of $\beta$-lactamase-mediated resistance. J Antimicrob Chemother 2001;48:1:59-64.

13. Ikryannikova $L N$, Shitikov EA, Zhivankova DG, II'ina $E N$, Edelstein MV, Govorun VM. A MALDI TOF MS-based minisequencing method for rapid detection of TEM-type extended-spectrum beta-lactamases in clinical strains of Enterobacteriaceae. J Microbiol Methods 2008;75:385-91.

14. Knabl L, Grutsch I, Orth-Höller D. Comparison of the BD MAX Enteric Bacterial Panel assay with conventional diagnostic procedures in diarrheal stool samples. Eur J Clin Microbiol Infect Dis 2016;35(1):131-6.

15. Doğan M. Matriks aracılı dezorbsiyon iyonizasyon uçuş zamanı kütle spektrometresi (MALDI-TOF MS) sistemlerinin virolojide kullanımı. Altındiş $M$ (editör). Temel, Klinik ve Tanısal Tıbbi Viroloji. $7^{\text {st }}$ ed. Istanbul: Nobel Yayınevi, 2018:419-25.

16. Stverakova D, Sedo O, Benesik M, Zdrahal Z, Doskar J, Pantucek R. Rapid identification of intact staphylococcal bacteriophages using matrix-assisted laser desorption ionization-time-of-flight mass spectrometry. Viruses 2018;10(4):176.

17. Gür D, Gülay Z. EUCAST Klinik ve/veya epidemiyolojik önemi olan direnç mekanizmaları ve direnç özelliklerini saptama kılavuzu (Temmuz 2017): http://www.tmc-online.org/ userfiles/file/EUCAST-ceviri-2017.pdf.

18. Birgy A, Bidet P, Genel N, Doit C, Decre D, Arlet $G$, et al. Phenotypic screening of carbapenemases and associated $\beta$-lactamases in carbapenem-resistant Enterobacteriaceae. J Clin Microbiol 2012;50(4):1295-302.

19. Sakanashi $D$, Kawachi $M$, Uozumi $Y$, Nishio $M$, Hara $Y$, Hagihara $M$, et al. Evaluation of commercial phenotypic assays for the detection of IMP- or New Delhi metallo- $\beta$-lactamase-producing Enterobacteriaceae isolates in Japan. I Infect Chemother 2017;23(7):474-80.

20. Miriagou V, Cornaglia G, Edelstein M, Galani I, Giske CG, Gniadkowski $M$, et al. Acquired carbapenemases in gram-negative bacterial pathogens: detection and surveillance issues. Clin Microbiol Infect 2010;16:112-22.

21. Ribeiro V, Linhares AR, Zavascki AP. Performance of quantification of Modified Hodge Test: an evaluation with Klebsiella pneumoniae carbapenemase-producing Enterobacteriaceae isolates. Biomed Res Int 2014;6:25-64.

22. Legese $M H$, Weldearegay GM, Asrat D. Extended-spectrum beta-lactamase- and carbapenemase-producing Enterobacteriaceae among Ethiopian children. Infect Drug Resist 2017;25(10):27-34

23. Pasteran F, Mendez T, Guerriero L, Rapoport M, Corso A. Sensitive screening tests for suspected class $A$ carbapenemase production in species of Enterobacteriaceae. I Clin Microbiol 2009;47(6):1631-9.

24. Espinosa RF, Rumi V, Marchisio M, Cejas D, Radice M, Vay $C$, et al. Fast and easy detection of CMY-2 in Escherichia coli by direct MALDI-TOF mass spectrometry. I Microbiol Methods 2018;148:22-8.

25. Angeletti, S. Matrix assisted laser desorption time of flight mass spectrometry (MALDI-TOF MS) in clinical microbiology. J Microbiol Methods 2017;138:20-9. 
26. Kılıç Ü, Demiray T, Altındiş M. Karbapenemaz üreten Enterobacteriaceae izolatlarının saptanmasında fenotipik ve genotipik metotlar. Ankem Derg 2016;30(2):62-75.

27. Praveen $R, O m P$, Shouche, YS. Matrix-assisted laser desorption/ionization time-of-flight mass-spectrometry (MALDI-TOF MS) based microbial identifications: challenges and scopes for microbial ecologists. Front Microbiol 2016;7(4):13-59.

28. Hrabak J, Walkova R, Studentova V, Chudackova E, Bergerova $T$. Carbapenemase activity detection by matrix-assisted laser desorption ionization-time of flight mass spectrometry. J Clin Microbiol 2011;49(9):3222-7.

29. Knox J, Jadhav S, Sevior D, Agyekum A, Whipp M, Waring $L$, et al. Phenotypic detection of carbapenemase-producing Enterobacteriaceae by use of matrix-assisted laser desorption ionization-time of flight mass spectrometry and the Carba NP test. J Clin Microbiol 2014;52(11):4075-7.

30. Carvalhaes CG, Cayo R, Visconde MF, Barone T, Frigatto $E A$, Okamoto $D$, et al. Detection of carbapenemase activity directly from blood culture vials using MALDI-TOF MS: a quick answer for the right decision. J Antimicrob Chemother 2014;69(8):2132-6.
31. Johnson AP, Woodford N. Global spread of antibiotic resistance: the example of New Delhi metallo- $\beta$-lactamase (NDM)-mediated carbapenem resistance. I Med Microbiol 2013;62:499-513.

32. Kalem F, Ergun AG, Ertuğrul Ö, Özçimen S, Şimşek Ş, Süzük $S$, et al. Colistin resistance in carbapenem-resistant Klebsiella pneumoniae strains. Biomed Res 2016;27(2):368-72.

\section{Address for Correspondence/Yazıșma Adresi}

Doç. Dr. Metin DOĞAN

Necmettin Erbakan Üniversitesi Meram Tip Fakültesi, Tıbbi Mikrobiyoloji Anabilim Dalı, Meram, Konya-Türkiye

E-mail: metin_dogan42@yahoo.com 